International Journal of Linguistics, Literature and Culture
Available online at https://sloap.org/journals/index.php/ijllc/
Vol. 6, No. 1, January 2020, pages: 24-31
ISSN: 2455-8028
https://doi.org/10.21744/ijllc.v6n1.810

\title{
Comparative - Contrastive Analyze of Anthropomorphic Figures of Evil in English and Georgian Languages
}

Tamar Shiukashvili ${ }^{\text {a }}$

\section{Article history:}

Received: 27 September 2019

Accepted: 09November 2019

Published: 09 January 2020

\section{Keywords:}

anthropomorphic figures; anthropomorphism;

folk tales;

mythology;

typological analyses;

\begin{abstract}
The article deals with the research of anthropomorphic figures which is related to the evil in folk tales. According to this our aims to pursue a typological analysis of the English and Georgian folk tales Our research based on Georgian and English folk tales of XX-XIX centuries as the object of research - Georgian folk tales the publishing house "Nakaduli", Tbilisi 1976 year and the English folk tales collected by Joseph Jacobs http://www.surlalunefairytales.com/. The articles aimed to make a comparative-contrastive study of the anthropomorphic figures that are shown as evil faces in Georgian and English folk tales and it was discovered that throughout the study more similarities than differences were observed in both of the collections. It was also observed that Georgian and English folk tales represent universals expressed with the anthropomorphic figures of evil and deal with similar cultures. The article argues that anthropomorphic figures of evil in these folk tales result from the feeling of envy, jealousy, greed, dread or the struggle for power and superiority.
\end{abstract}

International journal of linguistics, literature and culture (C) 2020. This is an open access article under the CC BY-NC-ND license (https://creativecommons.org/licenses/by-nc-nd/4.0/).

Corresponding author:

Tamar Shiukashvili,

Doctor of Philology, Department of foreign languages and literature

Telavi State University, Georgia.

Email address: tamar.shiukashvili@tesau.edu.ge

a Telavi State University, Georgia 


\section{Introduction}

Folk art is a various and interesting phenomenon. It still records a positive contribution to the development of humanity. The main formation of the genius of the people is a fairy tale, which has the largest part information of people's outlook, despite the seeming simplicity and linearity (Yani et al., 2018; Edung et al., 2018).

Fairy folk wisdom is one of the oldest and popular genres. It was created orally by our ancestors a long time ago as they were illiterate and didn't know to write and read. By then people memorized these orally stories by listening and conveyed to posterity by heart again.

During the many hundreds of years, these verbal fantastic stories have moved around the corners and from generation to generation. The destination of the tale was especially great as long as the script developed by the people. But neither writing nor the book did not destroy tale. It was developing and spreading alongside the writers because it had its own function and tradition.

\section{Materials and Methods}

As it is known, the folklore tale is seen as related to the elements of the internal unity of the system caused by the formation of ideological and psychological content, motives, stories, genre composition and artistic styles of the signs.

\section{Results and Discussions}

The articles aimed to make comparative study anthropomorphic figures of evil in Georgian and British folk tales and it was discovered that throughout the study more similarities than differences were observed in both of the collections. It was also observed that Georgian and British folk tales represent universal psychological problems and deal with similar anxieties, regardless of culture.

The article argues that the anthropomorphic figures of evil in these fairy tales result from the feeling of envy, jealousy, greed, dread or the struggle for power and superiority. In these selected tales, the action of the anthropomorphic figures of evil is observed in the form of theft, violence, torture, transformation or even murder.

The term anthropomorphism is derived from the Greek words Anthropos (human) and morphe (form). Until the latter half of the nineteenth century, this term referred to the practices of attributing deities with humanlike characteristics or bodily form, but in the first decades of the twentieth century, anthropomorphism came to be regarded, in a pejorative sense, as the attribution of uniquely human characteristics to nonhuman animals (Molloy, 2006; Bahri, 2017; Nazara et al., 2019).

Folk tales are the artistic chronicle of the fight against evil. As for the plot of Georgian and English folklore, there are many names between two different languages of folk tales that served as a symbol of evil. On the basis of our research it is outlined that in Georgian and English folk tales as a symbol of evil there has been proved:

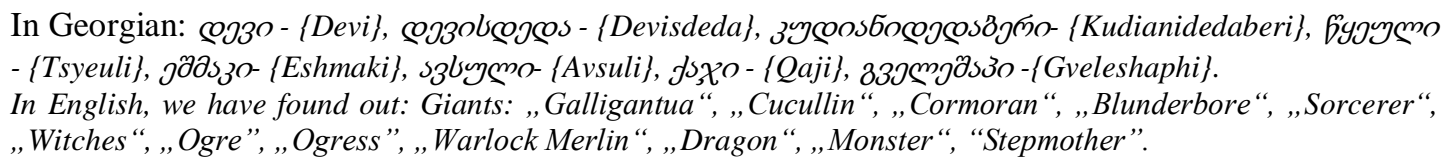

The difference is minor between the languages. It has been revealed that all magical folk tales reflect in the relation of contradiction where kindness always wins.

One of the important supernatural beings in Georgian fairytales is the giant called Devi, a representative of the principle of evil, but with certain limitations, neither incorporeal nor immortal, but half demon half man, i.e. an unclean spirit in the form of a giant. He is subject to death even a man can kill, cheat and terrify him; he can marry a woman. His nature is also ambivalent like the snake: sometimes he is an enemy but sometimes a friend of the hero (Gogiashvili, 2013; Bahri et al., 2018; Subawa et al., 2019).

Devi (@)3o) - Many-headed ogres whose heads can regenerate if any of them are cut off. These malevolent giants live in the underworld or in remote mountains, where they hoard treasure troves and keep their captives. In

Shiukashvili, T. (2019). Comparative - contrastive analyze of anthropomorphic figures of evil in english and georgian languages. International Journal of Linguistics, Literature and Culture, 6(1), 24-31. 
Georgian mythology, they live in a family, consisting usually of nine brothers. http://www.wikiwand.com/en/Georgian_mythology

In all cases, Devi is represented as an enemy of human beings in Georgian folk tales.

In some folk tales, his name is "Bakhbakh Devi" - „Osyßssy@330“(Georgian Folk Tale "Amirani”). Al. Glonti's observation, "Bakhbakh Devi" is a proper name (Glonti, 1974; Srivastava \& Mishra, 2016).

According to the Georgian mythology "Bakhbakh Devi" is the man of the forest, one of the faces of Devi. Baqqah-Devi, who symbolizes the evil origin (but always fails by a positive hero), is a great creature whose gravity hardens the earth, a man who eats humans with his helpers http://www.wikiwand.com/en/Georgian_mythology

Bakbak-Devi (3sy3sy-(0330) was the strongest and the most powerful of the devices. To defeat them, heroes would outwit them by means of various tricks and games. Their name (a borrowing into the Kartvelian (language family) Georgian language from Indo-European) is related to that of the daevas of Zoroastrian and Persian mythology, derived in turn from Proto-Indo-European *deiúó 'god' http://www.wikiwand.com/en/Georgian_mythology

In our opinion, it is more epithet and should be noted: different from others, stronger, more celebrated, unsuspecting, etc. However, Al. Glonti adds that the names that are known as epithets in folk tales considered as their proper names (Glonti, 1974; Aini, 2017; Geba et al., 2018).

In English folk tales Giant is the synonym of Georgian Devi. The Giant has found in its proper names: „Galligantua“, ,Cucullin“, „,Cormoran“, and „Blunderbore“. He is also the enemy of human beings - with two heads and sometimes many heads. He is a huge giant with eighteen-foot in height and about three yards round the waist. It is interesting that Giant can be found in different nuances in English folk tales. He is the owner and lord of the sarcas and domes, sometimes he is taken possession of the mountain, but from time to time he is a shepherd in the field. There are examples that convince us that in those times they exist indeed.

In those days the Mount of Cornwall was kept by a huge giant named Cormoran. He was eighteen feet in height and about three yards round the waist; of a fierce and grim countenance, the terror of all the neighboring towns and villages" http://www.surlalunefairytales.com/authors/jacobs/english/jackgiantkiller.html

On the top of the mountain is an enchanted castle; this is kept by a giant named Galligantua http://www.authorama.com/english-fairy-tales-21.html

There was at that time another giant, named Cucullin http://www.surlalunefairytales.com/authors/jacobs/celtic/legendknockmany.html

The news of Jack's victory soon spread over all the West of England, so that another giant, named Blunderbore, hearing of it, him" http://www.authorama.com/english-fairy-tales-21.html

In English folk tales "Giant", like Georgian "Devi", is a man. He likes the human flesh as Devi loves. This is an example of one of the folk tales:

We are kept here, said one, till such time as the giants have a wish to feast, and then the fattest among us is slaughtered! And many are the times they have dined upon murderedmen! http://www.surlalunefairytales.com/authors/jacobs/english/jackgiantkiller.htm

In English folk tales Giant has often replaced the Ogre. Ogre is a legendary monster usually depicted as a large, hideous, man-like being that eats ordinary human beings, especially infants and children. Ogres frequently feature in mythology, folklore, and fiction throughout the world.

In mythology, ogres are often depicted as inhumanly large and tall and having a disproportionately large head, abundant hair, unusually colored skin, a voracious appetite, and a strong body. Ogres are closely linked with giants and with human cannibals in mythology. In both folklore and fiction, giants are often given ogrish traits (such as the giants in "Jack and the Beanstalk" and "Jack the Giant Killer"https://en.wikipedia.org/wiki/Ogre

There has been proved the example from the English folk tale "Jack the Giant Killer" "So the ogre went off, and Jack was just going to jump out of the oven and run off when the woman told him not. "Wait till he's asleep," says she; "he always has a snooze after breakfast. Well, the ogre had his breakfast, and after that, he goes to a big chest and takes out of it a couple of bags of gold and sits down counting them till at last his head began to nod and he began to snore till the whole house shook again" http://www.surlalunefairytales.com/authors/jacobs/english/jackgiantkiller.html

There are various kinds of witches in Georgian folk tales. One of them is ,,devis deda \{co3ol cojcos\} - "the mother of the devi". She is dangerous but if the hero speaks politely and respectfully to her, she will help him.

Further witches in Georgian folk tales is "dedaberi \{cosos 8 gno\}-The old wise woman. All of them have an ambivalent nature. Whether they show their negative power depends on the hero's behavior. (Gogiashvili, 2013). 
It is noted that in Georgian folk tales there are various kinds of portraits of dedaberi \{cojos $\partial j$ mo - (the old

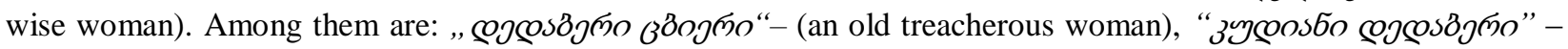

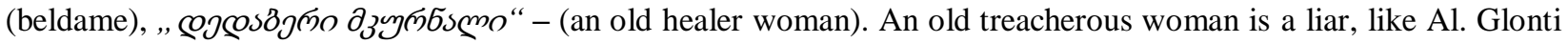
notes (Glonti et al., 1963), she is jealous; here is an example of Georgian folk tales.

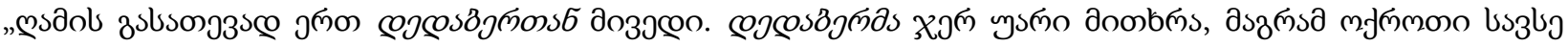

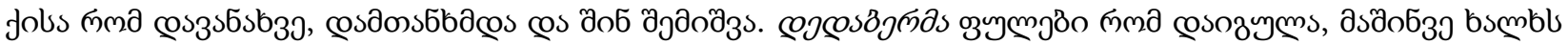

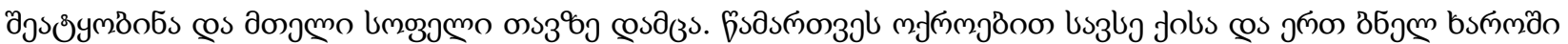

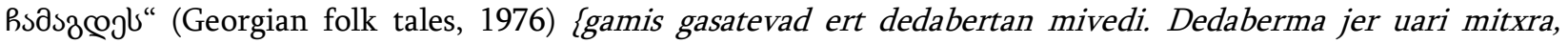
magram oqroti saves qisa rom davanaxe, damtanxmda da shin shemishva. Dedaberma pulebi rom daigula, mashinve xalxs sheatyobina da mteli sopeli tavze damca. Tsamartves oqroebit savse qisa da ert bnel kharoshic hamagdes - "I went to Dedaberi to spend the night. The mother has just refused me yet, but when I saw a purse full of gold, she agreed to me and gave me her place where she lived. When Dedaberi kept the money, she immediately informed the people. They took me the whole gold and drop in a dark pit" [Translated by Tamar Shiukashvili].

Kudiani (zycoos6o) - A type of hideous hunchbacked witch, having large teeth and a tail, from the latter of which her name is derived (kudi, зyœo, "tail") http://www.wikiwand.com/en/Georgian_mythology. She is a form of evil. Outwardly she is a kind with a sweet word that mocks her sacrifice, materially she has a bad and evil soul. She takes different poses to persuade naive people younger and give them a trap. Because of this people called her a Beldame (Glonti et al., 1963).

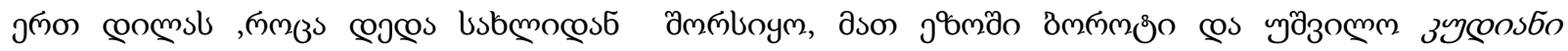

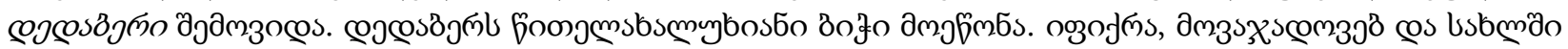

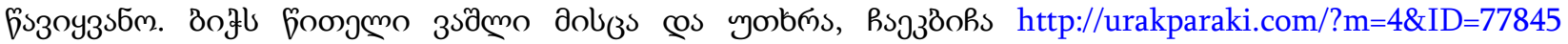
[Georgian folk tale: the folk tales about rainbow]. \{ertdilas, roca deda saxlidan shors iyo, mat ezoshi boroti da ushvilo kudiani dedaberi shemovida. Dedabers tsitel axaluxiani bichi moetsona. Ifiqra, movajadoveb da saxlshi tsaviyvano. Bichs tsiteli vashli mistsa da utxra, chaekbicha\} - "One morning when the mother was away from the house, jealous and childless Kudiani Dedaberi (beldame) came in their garden. Kudiani Dedaberi (beldame) liked the boy who is dressed in red clothes. She thought she would bewitch him and would take him home. She gave the red apple to him and asked him to take a bite" [Translated by Tamar Shiukashvili].

In Georgian folk tales sometimes Dedaberi (an old healer woman) is a doctor. In one cycle of folklore stories, she

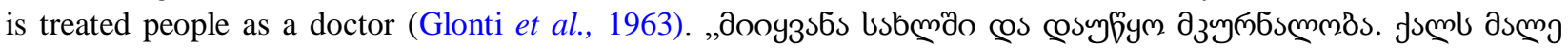

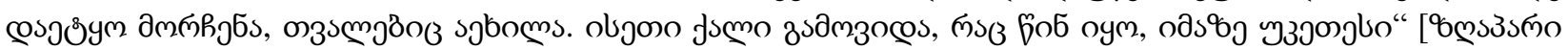
yshs@göobs] [zgapariyachagebisa\}, Georgian folk tale about the robber, 1952: 297-298] [miiyvanasaxlshi da dautsyomkurnaloba. Qals male daetyomorchena, Tvalebicaexila. Isetiqaligamovida, ractsiniyo, imazeuketesi\} "She brought a woman at home and started treatment. Soon the woman is getting better and opened her eyes. A woman came out of the way, better than she was. There has been proved the evil face "Ogre's wife" in English tales [Translated by Tamar Shiukashvili].

„Well, the ogre's wife was not half so bad after all. So she took Jack into the kitchen and gave him a hunk of bread and cheese and a jug of milk"http://www.surlalunefairytales.com/authors/jacobs/english/jackbeanstalk.html

As in Georgian folk tales, in English folks, there are also revealed one of the evil faces of the woman and it is called - Witch, Sorcerer.

Old English witch "female magician, sorceress," in later use especially "a woman supposed to have dealings with the devil or evil spirits and to be able by their cooperation to perform supernatural acts" http://www.etymonline.com The action of Witch is clearly seen in one of the examples of English folk tales.

"The third daughter says to her mother: Mother, bake me a bannock, and roast me a collop, for I'm going away to seek my fortune. Her mother did so, and away she went to the old witch. She bade her look out of her back door, and see what she could see. She did so; and when she came back, said she saw naught. The second day she did the same and saw naught. The third day she looked again, and on coming back said to the old wife, she saw naught but a great Black Bull coming crooning along the road. "Well, quoth the old witch, "yen's for you." On hearing this she was next to distracted with grief and terror, but she was lifted up and set on his back, and away they went" http://www.surlalunefairytales.com/authors/jacobs/moreenglish/blackbull.html

Shiukashvili, T. (2019). Comparative - contrastive analyze of anthropomorphic figures of evil in english and georgian languages. International Journal of Linguistics, Literature and Culture, 6(1), 24-31. https://doi.org/10.21744/ijllc.v6n1.810 
In the English folk tale, there is one such face, "Warlock Merlin". The etymological dictionary explains: „Warlock”- Old English wærloga "traitor, liar, enemy, devil," http://www.etymonline.com

So Childe Rowland said good-bye to the good queen, his mother, and went to the cave of the Warlock Merlin. "Once more, and but once more," he said to the Warlock, "tell how man or mother's son may rescue Burd Ellen and her brother's twain."

In many Georgian folktales, we have found one of the figures of evil Gveleshapi - a feature, a supernatural being with an ambivalent character: the Gveleshapi ("snake-whale") which represented the dragon. In general, the word dragon in the folklore of the peoples of Europe (as well as its variants such as German Drache, English dragon) is derived from the Latin word Draco, which means 'snake' (Gogiashvili, 2013).

In English folk tales, unlike Georgian, there has revealed the "Dragon" and "Monster". According to the etymological dictionary, Dragon is explained as follows - a fabulous animal common to the conceptions of many races and peoples, from Old French dragon and directly from Latin Dragoness (nominative Draco) https://www.etymonline.com

In etymology, Monster derives from the Latin monstrum, "a strange, unnatural, hideous person, animal, or thing," or any "monstrous or unusual thing https://www.etymonline.com

In many English tales, it has been outlined that we have found the Dragon as a synonym of Monster. „And soon he heard it coming, roaring and raging from afar off, and at last it came near, spitting fire, and with a tongue like a great spear, and you could hear it roaring for miles, and it was making for the place where the king's daughter was staked down. But when it came up to them, the lad just hit it on the head with the bladder and the dragon fell down dead, but Before it died, it bit off the little boy's forefinger" http://www.surlalunefairytales.com/authors/jacobs/moreenglish/littlebullcalf.html

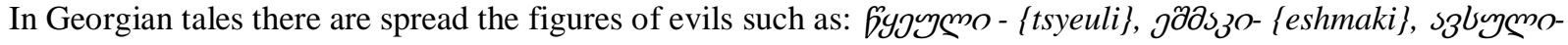

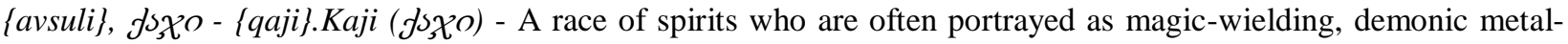
workers (compare Sons of Ivaldi). They lived in Kajeti (f১భృono) and had magic powers that they used against humans http://www.wikiwand.com/en/Georgian_mythology.

Tsyeuli (fyJymo) - has all the attributes of the wicked. Sulkhan-Saba Orbeliani explains Tsyeuli (69Jygo) as cursed" (Orbeliani, 1949). This term is often synonymous with function. Even today, we are often used to describe the "Snake" in oral speech. According to the folk tales, Tsyeuli (fygymo) is called Avsuli (szlymo) and it is a symbol to release of a man from the evil spirit". In Georgian folk tales, Avsuli (szlymo) is called gzдszo\{eshmaki\}. Stepmother is also related to the evil in both research languages. The term "stepmother" is defined by the Cambridge Dictionary of English - the woman who is married to someone's father but who is not their real mother https://dictionary.cambridge.org/dictionary, who is often evil, jealous to her stepchild in folk tales. The figure of the stepmother as Georgian folk tales so the English folk tales are actually not really different from the figure of other stepmothers.

Stepmothers are almost invariably depicted as wicked, the stepchild as their completely innocent victim. This may be explained in terms of both the one-dimensional character of the folktale (Watson, 1995).

The stepmother was angry, but she pretended not to mind the loss. She said to the child: "Come, lay your head on my lap that I may comb your hair." So the little one laid her head in the woman's lap, who proceeded to comb the yellow silken hair. And when she combed, the hair fell over her knees and rolled right down to the ground. Then the stepmother hated her more for the beauty of her hair; so she said to her: "I cannot part your hair on my knee, fetch a billet of wood." So she fetched it. Then said the stepmother, "I cannot part your hair with a comb, fetch me an axe." So she fetched it.http:/www.sacred-texts.com/neu/eng/eft/eft04.htm

In Georgian folk tales "Tsiqara" "The stepmother learned the story about the friendship between the bull and the boy and get worse. She realized that she could not do anything until her stepchild had a tsiqara in his sideways, and decided to get rid of it. She pretended that she was ill and asked her husband to help her.

\section{Conclusion}

In conclusion, Folk tales, first of all, are fictional fights against evil. In Georgian folk tales the symbol of evil is

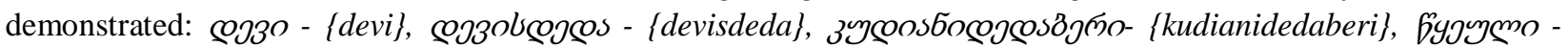

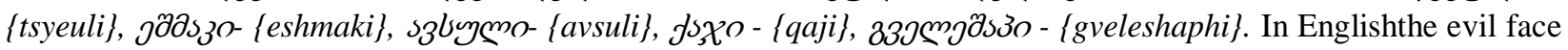


is shown as : Sorcerer“, “Giant” „Witches“, „Ogre”, „Ogress”, „,Warlock Merlin“, „Dragon“, „Monster“, "Stepmother".

After comparative-contrastive analyses of our research, we find out that the anthropomorphic figures of evil are the cultural universals in both research languages. The distinction between the analytical languages in this respect is insignificant. Rarely, however, in both fairy tales, their goal is humane.

\section{Conflict of interest statement and funding sources}

The author declared that she has no competing interests.

Statement of authorship

The author has a responsibility for the conception and design of the study. The author has approved the final article.

\section{Acknowledgments}

The authors would like to thank the reviewer for their consideration of the further process of the present paper. Thanks to the editor of IJLLC for the valuable support, time as well as advice. 


\section{References}

Aini, Z. (2017). The actualization of cultural elements in novel Guru Onyeh by Salman Faris. International Journal of Social Sciences and Humanities, 1(3), 17-27. https://doi.org/10.29332/ijssh.v1n3.49

Bahri, S. (2017). The relation between Sasak and Samawa folktales: Comparative literature to multicultural education. International Journal of Linguistics, Literature and Culture, 3(1), 75-85.

Bahri, S., Rusdiawan, -, \& Nuriadi, -. (2018). Comparison of expression of God in poems written by Amir Hamzah, Chairil Anwar and Sutardji Calzoum Bachri. International Journal of Linguistics, Literature and Culture, 4(3), 64-71.

Edung, T., Triguna, I. B. Y., \& Utama, I. W. B. (2018). Balian Wara position of Dayak Lawangan. International Journal of Linguistics, Literature and Culture, 4(4), 103-111. https://doi.org/10.21744/ijllc.v4n4.272

Geba, T., Hoban, N., \& Rambut, K. (2018). Descendants of Ndori clan: Lio ethnic Ende regency. International Journal of Social Sciences and Humanities, 2(2), 54-64. https://doi.org/10.29332/ijssh.v2n2.125

Glonti, A. A. (Ed.). (1974). Gruzinskie narodnye novelly. Izd-vo" Merani".

Glonti, al. (1963). Georgian folk narrative. Tbilisi: State publishing house "Soviet Georgia".

Gogiashvili, E. (2013). About Georgian Fairytales. Bulletin de l'Académie Belge pour l'Étude des Langues Anciennes et Orientales, 159-171.

Mooley, C. (2006). Discourses of Anthropomorphism, Liverpool John Moores University.

Nazara, W., Sudipa, I. N., Artawa, K., \& Satyawati, M. S. (2019). Causative constructions in the language of nias. International Journal of Social Sciences and Humanities, 3(2), 208-216. https://doi.org/10.29332/ijssh.v3n2.316

Orbeliani, S. S. (1949). "Word of the English, which is the dictionary". S Iordanishvili edition and foreword. Tbilisi: SSR State publishing house.

Srivastava, S., \& Mishra, S. K. (2016). Indian and French philosophical literature: in search of wisdom, spirituality, and rationalism. International Journal of Linguistics, Literature and Culture, 2(4), 81-85.

Subawa, I. B., Gelgel, I. P., \& Subrata, I. W. (2019). Existence of Bali Aga community religion. International Journal of Social Sciences and Humanities, 3(1), 72-81. https://doi.org/10.29332/ijssh.v3n1.256

Watson, P. A. (1995). Ancient stepmothers: myth, misogyny and reality (Vol. 143). Brill.

Yani, L., Artawa, K., Satyawati, N. M. S., \& Udayana, I. N. (2018). Transitivity construction of verbal clause in Ciacia language. International Journal of Linguistics, Literature and Culture, 4(3), 15-23.

http://www.etymonline.com

http://urakparaki.com/?m=4\&ID=77845

https://en.wikipedia.org/wiki/Ogre

http://www.wikiwand.com/en/Georgian_mythology

https://dictionary.cambridge.org/dictionary

http://www.surlalunefairytales.com/authors/jacobs/english/jackgiantkiller.html

http://www.authorama.com/english-fairy-tales-21.html

http://www.sacred-texts.com/neu/eng/eft/eft04.htm

http://www.surlalunefairytales.com/authors/jacobs/celtic/legendknockmany.html

http://www.surlalunefairytales.com/authors/jacobs/english/jackbeanstalk.html

http://www.surlalunefairytales.com/authors/jacobs/moreenglish/blackbull.htmlhttp://www.surlalunefairytales.com/au thors/jacobs/moreenglish/littlebullcalf.html 


\section{Biography of Author}

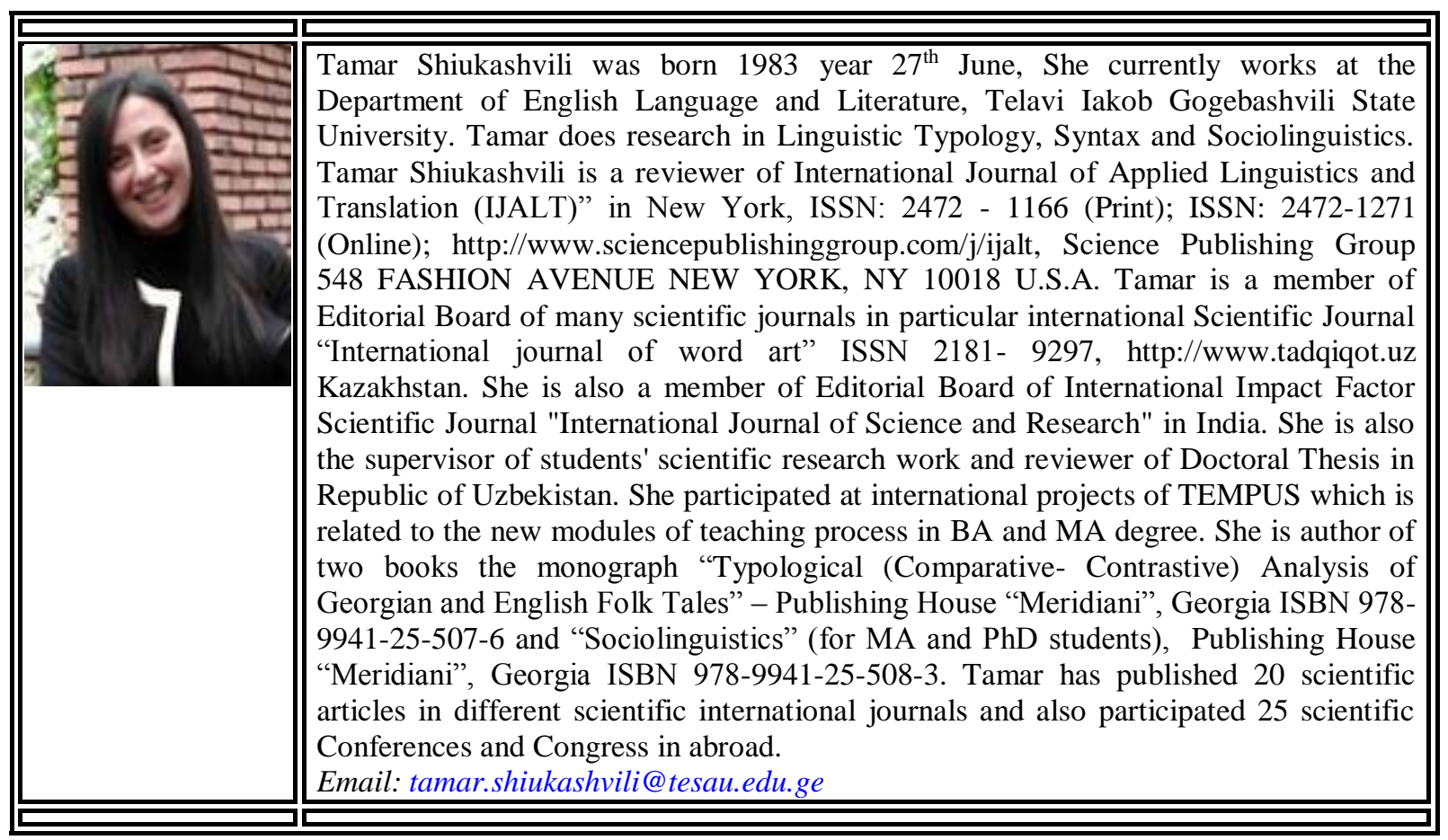

Shiukashvili, T. (2019). Comparative - contrastive analyze of anthropomorphic figures of evil in english and georgian languages. International Journal of Linguistics, Literature and Culture, 6(1), 24-31. 